\title{
Comparing Germany and Israel regarding debates on policy-making at the beginning of life: PGD, NIPT and their paths of routinization
}

\author{
Aviad E. Raz • Tamar Nov-Klaiman • Yael Hashiloni-Dolev • \\ Hannes Foth · Christina Schües · Christoph Rehmann-Sutter
}

Received: 25 January 2021 / Accepted: 1 July 2021 / Published online: 31 August 2021

(C) The Author(s) 2021

\begin{abstract}
Definition The routinization of prenatal diagnosis is the source of bioethical and policy debates regarding choice, autonomy, access, and protection. To understand these debates in the context of cultural diversity and moral pluralism, we compare Israel and Germany, focusing on two recent repro-genetic "hot spots" of such policymaking at the beginning of life: pre-implantation genetic diagnosis (PGD) and noninvasive prenatal genetic testing (NIPT), two cutting-edge repro-genetic technologies that are regulated and viewed very differently in Germany and Israel, reflecting different medicolegal policies as well as public and bioethical considerations.

Arguments First, we compare policy-making in the context of PGD for HLA (human leukocyte antigen) typing, used to create sibling donors, approved in Israel under specific conditions while prohibited in Germany. Second, we compare policy-making

Prof. Dr. Aviad E. Raz · Tamar Nov-Klaiman · Prof. Dr. Yael Hashiloni-Dolev

Dept. of Sociology and Anthropology, Ben-Gurion University of the Negev, Beer-Sheva, Israel

Prof. Dr. Aviad E. Raz

E-Mail: aviadraz@bgu.ac.il

Tamar Nov-Klaiman

E-Mail: tamarnk@gmail.com

Prof. Dr. Yael Hashiloni-Dolev

E-Mail: yaelhd@bgu.ac.il

Hannes Foth · Prof. Dr. Christina Schües · Prof. Dr. Christoph Rehmann-Sutter $(\varangle)$

Institute for History of Medicine and Science Studies, University of Lübeck,

Königstraße 42, 23552 Lübeck, Germany

E-Mail: christoph.rehmannsutter@uni-luebeck.de

Hannes Foth

E-Mail: foth@phil.hhu.de

Prof. Dr. Christina Schües

E-Mail: c.schuees@uni-luebeck.de
\end{abstract}


in the context of NIPT, which came under fire in Germany, while in Israel there has been little public debate about it.

Conclusion Both countries justify their contrasting policies as reflecting a concern for the well-being and care of the embryo/child, thus highlighting different concepts of embryo/child protection, (relational) autonomy, family relations, and the impact of religion and history on the promotion/protection of life. We use the juxtaposition of PGD and NIPT to highlight some inconsistencies in policies concerning the protection of extra- and intra-corporeal embryos. We conclude by drawing on the comparison to show how national variations exist alongside co-evolution.

Keywords Prenatal testing · Preimplantation diagnosis - Cross-cultural bioethics · Policy-making $\cdot$ Reproductive genetics

\section{Vergleichende Untersuchung der Debatten in Deutschland und in Israel über politische Entscheidungsprozesse am Lebensanfang: PID, NIPT und ihr Weg zur Routinisierung}

\section{Zusammenfassung}

Definition Die Routinisierung der Pränataldiagnostik hat bioethische und regulatorische Debatten ausgelöst: über Freiheit, Autonomie, Zugang und Schutz. Um diese Debatten im Kontext von kultureller Diversität und ethischem Pluralismus verstehen zu können, vergleichen wir Israel und Deutschland. Dabei fokussieren wir auf 2 jüngere reprogenetische „Hotspots“ der Biopolitik am Lebensanfang: Präimplantationsdiagnostik (PID) und nichtinvasive genetische Pränataltests (NIPT) 2 innovative reprogenetische Technologien, die in Deutschland und Israel sehr unterschiedlich betrachtet und reguliert werden. Darin spiegeln sich Unterschiede wider, sowohl in der Politik zu medizinrechtlichen Vorgaben als auch in gesellschaftlichen und bioethischen Überlegungen.

Argumentation Zunächst vergleichen wir die Regulierung im Zusammenhang mit der PID für die HLA(,,human leukocyte antigen“)-Typisierung mit dem Ziel der Erzeugung passender Gewebespender. In Israel ist diese unter bestimmten Bedingungen zulässig, in Deutschland dagegen verboten. Anschließend vergleichen wir die Regulierung im Kontext mit NIPT, die in Deutschland in die Kritik gerieten, während in Israel dazu nur wenig öffentlich debattiert wurde.

Schlussfolgerung Beide Länder begründen ihre gegensätzlichen Regulierungen als Ergebnis des Bemühens um das Wohlergehen und die Versorgung des Embryos/ Kindes. Zum Ausdruck kommen darin wodurch unterschiedliche Konzepte zu Embryonen-/Kinderschutz, (relationaler) Autonomie und Familienbeziehungen sowie unterschiedliche Einflüsse religiöser Überzeugungen und geschichtlicher Erfahrungen auf die Förderung/den Schutz des Lebens. Wir setzen kasuistische Gegenüberstellungen zu PID und NIPT ein, um auf einige Inkonsistenzen in den politischen Strategien zum Schutz von extra- und intrakorporalen Embryonen hinzuweisen. Abschließend wird anhand des Vergleichs dargestellt, wie nationale Besonderheiten neben einer Koevolution biomedizinischer Praktiken bestehen. 
Schlüsselwörter Pränataldiagnostik · Präimplantationsdiagnostik · Interkulturelle Bioethik · Entstehungsprozesse politscher Regulierung $\cdot$ Reproduktive Genetik

\section{Introduction}

Technological practices of reproductive genetics at the beginning of life open new possibilities for planning and shaping life, while also involving risks and responsibilities that raise social and ethical debates (Schües and Rehmann-Sutter 2013; Wiesemann 2006; DeGrazia 2012; Kollek 2002; McGee 2000; Heyd 1998). This paper looks into policy making and its related debates at the beginning of life in the context of repro-genetic technologies from a cross-cultural perspective. For this purpose we focus on pre-implantation genetic diagnosis (PGD) and non-invasive prenatal genetic testing (NIPT), two cutting-edge repro-genetic technologies that are regulated and viewed very differently in Germany and Israel, reflecting contrasting medicolegal policies as well as public and bioethical considerations. Our methodological focus is on highlighting and comparing the differences between recent policies as well as their related debates as gleaned from relevant policy documents and the media, making PGD and NIPT important case studies for a crossnational comparison and allowing for an in-depth investigation. The comparison does not intend to answer which national outlook is better. By looking at the image of our familiar culture as it is reflected on and by the other side, the comparison is meant to produce fertile epistemological distancing and a hermeneutic repositioning from which the familiar can be seen in a new light (Raz and Schicktanz 2010).

PGD, the "older" of these two technologies, has generated a range of conflicting responses to fictional scenarios: It has been praised in the general context of "procreative beneficence" (Savulescu 2001; Harris 1998), criticized as a new form of eugenics undermining moral equality and self-determination (Habermas 2003; Sandel 2007) or leading to the commodification of "babies by design" (Woopen 1999; Benedict XVI, Sovereign Pontiff 2008). Germany and Israel represent substantial cross-cultural differences in the regulatory frameworks of PGD in general. In Israel there is a rather permissive regulatory framework enabling PGD also for less severe genetic diseases and late onset diseases (Ministry of Health, State of Israel 2013, 2006). In addition, PGD is funded by the state under limited conditions (Löwy 2020). In contrast in Germany, within the framework of the embryo protection act, PGD was legally restricted until 2011, and is currently implemented only for lifethreatening genetic diseases. To demonstrate and explore the diversity in regulation and moral evaluation of PGD (Hens et al. 2013), we focus here on PGD for HLA (human leukocyte antigen) typing, used to create sibling donors. HLA-PGD represents an extreme case because it is banned in one country and approved in the other. In addition, HLA-PGD - more than other PGD applications - brings to the forefront arguments on the benefit/harm to the fetus in comparison to the benefit/harm to another stakeholder and the legitimacy of such evaluation. Both countries justify their contrasting policies as reflecting a concern for the well-being and care of the embryo/(sick) child, thus highlighting different concepts of embryo/child protection, 
(relational) autonomy, family relations, and the impact of religion and history on the promotion/protection of life (Heyd 1998).

To further demonstrate and explore the diversity in regulation and moral evaluation in the context of prenatal screening (Asch and Barlevy 2012; Parens and Asch 2000; Reynolds 2003) we focus also on the new technology of non-invasive genetic testing (NIPT; Labonté et al. 2019). As NIPT is being introduced globally, its clinical implementation reinvokes various challenges, including the disability critique on prenatal screening, informed choice of women, information overload, and access (Ravitsky et al. 2021; Haidar et al. 2020; Labonté et al. 2019; Griffin et al. 2018). While NIPT was criticized by German disability rights groups as well as some health organizations and Christian groups (see later), in Israel there has been no public debate about it. However in Germany, NIPT is planned to be covered by public health insurance on a case-by-case basis and included in the maternity care guidelines (Mutterschaftsrichtlinien), while Israel has decided not to include NIPT into the standard public health offer ("health basket").

In terms of methodology, our analysis is based on regulatory and policy documents generated by relevant stakeholders, as well as on the associated discourses that followed the introduction of PGD and NIPT in both countries. Documents include position statements issued by professional medical organizations, ethics committees, religious institutions, social networks, and state agencies, including the relevant laws. There is, however, a clear difference between Germany and Israel regarding the amount of available material. This might reflect the way in which these technologies are perceived in each country. The introduction of both technologies in Germany generated fierce controversies and debates, involving diverse stakeholders, and resulted in the publications of many documents, including a change in the law concerning the use of PGD. In Israel, on the other hand, the stakeholders involved in the debates were less varied resulting in fewer documents that were, overall, supportive of the technologies. We refer to the main stakeholders involved in each country and their official stance.

In the following we begin the comparison of policy-making in the context of PGD for HLA and then move to NIPT. We show that while PGD-HLA provides a starker comparison of banning vs. promotion, NIPT provides a more nuanced example of different politics of provision as indications of policymaking in different cultural contexts. To conclude, both technologies are discussed as highlighting inconsistencies in policies concerning the protection of extra-corporeal (PGD) and intra-corporeal embryos (NIPT). We conclude by drawing on the comparison to show how national variations exist alongside co-evolution.

\section{PGD for HLA matching}

PGD for HLA matching involves in vitro fertilization and genetic diagnosis to produce a child with HLA properties matching those of an ill sibling and who is therefore a suitable stem cell donor for that sick child. Legally, socially and ethically acceptable in Israel as a life-saving procedure (Zuckerman et al. 2018; Ministry of 
Health, State of Israel 2013, 2006; Israeli Parliament 2005; Revel 2008), ${ }^{1}$ PGD for HLA matching is allowed for the parents of a child sick with a disease that can only be treated by transplanting cord blood or bone marrow from a tissue-matched firstdegree relative donor, provided that other treatment alternatives (such as the option of looking for an unrelated donor) have been considered, the diagnosed "pre-embryo" will not be harmed by the procedure, and that any excess "pre-embryos" will be kept frozen. An Israeli couple was the second in the world to successfully use this procedure (Harari 2005). Israelis who commented on the book (called A Present for the Future; Harari 2005) written by the mother, agreed on the benefit and virtue of HLA-PGD. It was referred to as "brave parenthood," "medical pioneering," "boundary breaking," and "exceptional human power" (Raz et al. 2017).

The ethical argument in favor of HLA-PGD stresses that as long as the new child is wanted and loved, and is not perceived as an instrument, it is beneficial to select for a healthy embryo that could also serve as a donor (Revel 2008). The Israeli argument also emphasizes the agony of the parents whose child is dying without a donation: "In their time of crisis, PGD could aid in bringing another child into the world and serve as a double blessing" (Revel 2008, pp. 99-100).

The positive reception of PGD in Israel also has a Jewish context. According to Jewish rabbinical law embryos acquire moral status gradually, after 40 days of gestation and while developing in the womb. The disposal of undesired IVF zygotes or "pre-embryos" is hence not considered equivalent to abortion. In fact, PGD is recommended by many Rabbis for at-risk couples. In 2005, Israel was also the first country in the world to authorize PGD for non-medical sex selection, under highly restricted conditions and regulations (Landau 2008). Israeli hospitals allegedly also offer PGD to the parents of autistic children who wish to have a girl to reduce the risk of autism (Even 2013), estimated as more prevalent in boys.

The prohibition of PGD in Germany, until 2010, had been inferred from the Embryo Protection Law (1990), which however did not explicitly mention or describe the procedure of PGD. In 2010 the German Federal Court decided that extracorporeal fertilization and testing for severe genetic defects actually is not included in the scope of forbidden practices and therefore is not illegal. ${ }^{2}$ In 2011 the Parliament ruled that PGD should be forbidden in principle but with the crucial exception of negative selection against severe illnesses (Richter-Kuhlmann 2011) or to prevent miscarriage or stillbirth. This has opened a gap for using PGD to select also against aneuploidies, which are correlated to higher risks of miscarriage or stillbirth (RehmannSutter 2017). This restricted legalization of PGD, which bans PGD for HLA, was the outcome of heated discussions. The issue continues to be debated in the German Ethics Council, the Medical Assembly, the Churches, and in various public and academic organizations, with a range of different positions concerning the moral status of an embryo, the social impact of genetic testing, and concerns of repeating abhorrent eugenic practices (Valkenburg and Aarden 2011; Kollek 2002; Schwinger 2003; Düwell et al. 1998; Maio 2007; Merkel 2002; Wiesemann 2006). In some

\footnotetext{
1 These are the most recent policy papers, showing that the practice has become established and even taken-for-granted.

2 Federal Court of Justice (BGH 2010) Decision 6 July 2010_5 StR 386/09.
} 
families, however, children may become (without PGD) donors of hematopoietic stem cells required to treat a sibling affected by leukemia or another blood related disease (Herzog et al. 2021). Following parental consent, a healthy child may be subjected to an invasive medical procedure to help an affected sibling (Schües and Rehmann-Sutter 2015). Usually, the law allows for medical interventions to take place only where medically indicated for the individual - a prerequisite that is not met in these cases of "savior siblings". The parents are legally required to provide proxy consent for their healthy child, if histocompatible, to act as donor and legally only if no unrelated donor could be found (Transplantation Act $\S 8 \mathrm{a}$ ).

In PGD for HLA, the parents anticipate and create the necessary conditions for sibling donation (Rehmann-Sutter 2007). While donation by already existing siblings is practiced, Germany prohibits the use of PGD to select for such donor siblings. Following a discussion in 2011 in the German Ethics Council, at the end the dominant argument was that other possibilities to treat a sick child should be prioritized, such as enlarging the net of HLA donors (Deutscher Ethikrat 2011). There was a concern that selection through HLA-PGD may lead to a eugenic slippery slope of "designing" children and instrumentalizing the life of these "spare parts supplier", with possible adverse impacts on the physical and emotional welfare of sibling donors as well as on their autonomy and dignity. Further arguments against PGD for generating savior siblings were quite specific, concerning for example the disposing of embryos and the selection of one embryo over another according to a particular criterion that relates to someone else, i.e. the sick child. Another argument was that parents could feel pressured to be "good parents" to create such a child (see also Habermas 2003; Henning 2014; Schües 2017).

\section{NIPT in Germany: Navigating in stormy waters}

The most widely used methods for obtaining a fetal sample for prenatal genetic testing are amniocentesis and chorionic villus sampling, both invasive and thus carrying a small risk of miscarriage. Non-invasive prenatal genetic testing (NIPT) uses cellfree fetal DNA in the maternal circulation (Smith and Visootsak 2013). Although NIPT's development and marketing have been commercially driven by various private companies and originally aimed at the individual consumer, its advantages and popularity led to considerations of inclusion into the public health system in developed countries with universal health care. Trisomy 21, which causes Down syndrome, is commonly screened through the combined first trimester test-composed of maternal serum screening and an ultrasound measurement of nuchal translucency. These can detect approximately $90 \%$ of cases of trisomies (Al Mahri and Nicolaides 2019). As NIPT has far greater sensitivity (>99\%) and specificity from the point of view of increasing the detection rates of trisomy 21 and other genetic trisomies and conditions included in the NIPT package, it would be reasonable to use NIPT universally and routinely instead of the combined first trimester test. The American College of Medical Genetics and Genomics clearly recommends "informing all pregnant women that NIPT is the most sensitive screening option for traditionally screened aneuploidies (i.e., Patau, Edwards and Down syndromes)" (Gregg et al. 
2016, p. 1060). However, since it only tests for a selection of conditions it can also lead to false reassurance in the pregnant woman to expect a "healthy child".

In 2012, NIPT was first offered to German women in specialized prenatal centers (Schwerpunktpraxen), provided by the (then) German company LifeCodexx AG. Today, the offer of NIPT has become more routine, however not in a clearcut way. NIPT is offered/recommended as a private health investment (IGeL) to women who have an increased risk for trisomies or request to do the test. It requires a physician's referral, granted per the woman's request. The appropriate indication is still a matter of controversy. The introduction of NIPT in Germany was accompanied by public controversy (Braun and Könninger 2018). The former Federal Government Commissioner for Matters relating to Persons with Disabilities, Hubert Hüppe, tried already in 2012 to prevent the implementation of NIPT via a legal opinion (Rechtsgutachten), which denied the legitimacy of NIPT mainly based on the argument that it is of no medical use (as required by the Genetic Diagnosis Act, GenDG) and discriminates people with disabilities. "Pro-life" (Lebensschutz) groups and Christian groups have regularly organised demonstrations in front of the LifeCodexx AG headquarters in Konstanz. ${ }^{3}$ However, the majority of the German Ethics Council supported an implementation of NIPT within certain limits, namely the use of NIPT for women having an increased risk of a genetic condition, and by no means as part of mass screening.

In 2015, some medicoprofessional organizations such as the German Society of Ultrasound in Medicine and Fetal Medicine Foundation Germany recommended that even though cell-free DNA testing/NIPT should be offered in conjunction with a qualified ultrasound and following appropriate counselling, it can also be used as a primary screening method for trisomy 21 in pregnant women of every age and risk group. Following medicotechnological assessment whether NIPT should be covered by the mandatory health care services, initiated by the Federal Joint Committee (Gemeinsamer Bundesausschuss, G-BA) in 2016 (Rehmann-Sutter and Schües 2020), ${ }^{4} 20$ German disability advocacy organizations and networks that engage in women's health issued a protest claiming that NIPT has no therapeutic benefits and does not improve the medical care of the pregnant woman or the expectant child. In their words: "the prenatal search for genetic characteristics is not part of pregnancy care, but a selective search for unwanted deviations" (Gen-ethisches Netzwerk e. V. et al. 2017). However, other organizations such as the family advocacy group pro familia supported the test's limited funding to improve the options available to prospective parents (Pro familia Bundesverband 2019). These contrasting perspectives led to an ongoing parliamentary debate.

\footnotetext{
3 See the invitation note from the CDL (Christdemokraten für das Leben) an initiative of the Christian Democratic Party (CDU): Herzliche Einladung zur Demo gegen den PraenaTest am 16. Juli 2017 in Konstanz, https://cdl-online.net/herzliche-einladung-zur-demo-gegen-den-praenatest-am-16-juli-2017in-konstanz/543. (Accessed: 23 August 2017): "[p]rotestieren Sie so gegen den neuen, bedrohlichen Gentests (PraenaTest), der die vorgeburtliche Selektion von Menschen mit Behinderungen zum Ziel hat!" (protest the new, dangerous gene tests (PraenaTest), whose aim is the prenatal selection against people with disabilities! [translated by the authors]).

4 Cf. Gemeinsamer Bundesausschuss (G-BA) (2016).
} 
The most recent change regarding the handling of NIPT took place in September 2019. The Federal Joint Committee of healthcare providers decided that NIPT is to be covered, in justified individual cases and after medical consultation, by public health insurance. The Committee chairman and also the text of the decision stress that NIPT is not to be used as screening, and that the aim of the decision is to avoid as much as possible the invasive examinations (already covered by health insurance) and their related risk of miscarriage. ${ }^{5}$ All decisions about offering or using NIPT should be taken in individual cases only, in relation to the specific situation of the woman concerned, and never in a routinized way (Rehmann-Sutter and Schües 2020). Since testing for sex determination is explicitly forbidden for all genetic testing until 12 weeks of pregnancy (GenDG), any routines of NIPT offer and use-if implemented in Germany-will have to consider this restriction as well.

In the German public discourse surrounding NIPT, the reference to its "routinization" has been widely used in a negative tone; as an expression of institutional power, a symbol for rash decision-making, or an excuse for not deciding for oneself. Routinization was generally seen as a challenge for individual autonomy and family relationships. An article in Der Spiegel that appeared just before the decision of the G-BA in September 2019 captures this in saying: "Up to now it was a very individual decision to do the test. It would be different if the G-BA includes it in the maternity care guidelines. Then it would be an official recommendation" (translated by the authors). ${ }^{6}$

\section{Israel: On the way to a universal offer of NIPT?}

As in Germany, Israeli women are informed of NIPT by their gynecologists and geneticists. Although NIPT is currently not part of the Israeli "health basket" (meaning that its cost is not covered by the Ministry of Health like a public health service), various financial agreements exist between the seven private companies that offer NIPT in Israel and the Israeli Health Management Organizations (HMO) providing health insurance. These agreements as well as the specific insurance the woman holds determine the fraction paid for the test by the HMO and the fraction paid by the woman individually. The overall cost of NIPT in Israel is relatively high: around 3000-4000 NIS ( 700-1000€), compared to around 200-550€ in Germany. The difference in funding policies is interesting because Israel has a fully funded public screening program for trisomy 21 by means of biochemical testing in combination with ultrasound. Therefore, the Israeli decision not to fund NIPT (which is more efficient than the existing screening program) might seem counterintuitive. In Germany, on the other hand, the decision to fund NIPT, even if not in the form of mass screening, seems to reflect the considerable support by stakeholders and the public (Braun and Könninger 2018).

However, in 2019 the Israeli Society of Medical Genetics voted in favor of replacing the current biochemical screening with NIPT, as a first screening test in

\footnotetext{
5 https://www.g-ba.de/presse/pressemitteilungen/810/. Accessed: 14 July 2021.

6 Schmergal 2019
} 
all pregnancies. NIPT has been submitted to the Israeli "health basket" committee for inclusion but was rejected for economic reasons. There has been no public debate concerning NIPT in Israel. On the contrary, the chairperson of one of Israel's Down's syndrome advocacy organizations has even called upon the Israeli Government to subsidize NIPT and make it available to all women, arguing in a public letter published on the organization's website that "the cost of this test is an outrageous wrongdoing ... Since it is a blood test (a short and simple procedure) and since this test could prevent, for those who wish it, bringing into the world a child with special needs, it seems to us extremely important to reduce the costs of the test immediately and make it accessible." ${ }^{7}$ In 2019, a major Israeli hospital in TelAviv started offering, for the first time in Israel, NIPT to all pregnant women, starting from week 8, at the Genetics Lab of the hospital, for a reduced cost of 2600 NIS $(\sim 650 €)$. The service, following regular practice in Israel that applies to all providers, includes pre- and post-counseling. This local service may soon pave the way to further routinization in the universal offer of NIPT.

In sum, the comparison of NIPT regulations and debates in Germany and Israel highlights their different cultural discourses of disability rights and prenatal diagnosis. In Germany, following a long and heated debate, NIPT is to be funded but not routinized. In Israel, without any public debate, NIPT is also partly reimbursed but due to a different situated reasoning which stresses the maximization of detection through additional tests such as CMA (chromosomal microarray analysis), which is already widely used and funded when medically indicated. We now turn to discuss these situated reasonings in a comparative context.

\section{New-old broad socio-ethical debates}

HLA-PGD and NIPT are innovative reprogenetic technologies whose regulation and practice represent and refuel socio-ethical debates on existential questions of life and death. Their study enables to highlight, analyze and compare the socio-ethical scripts embedded in technological practices, scripts that are the result of values and norms that might be naturalized and forgotten once the technology is implemented, but still exert an important influence on the regulation, practice and utilization of the technology (Akrich 1992; Bowker and Star 1999). These two technological practices highlight three important inter-related analytical dimensions: (a) perceptions of the well-being of the embryo/fetus/child vis-a-vis parental reproductive autonomy and family values; (b) health governance; and (c) health policies of care/prevention. Each dimension carries bioethical questions that are culturally embedded.

First, HLA-PGD and NIPT provide important loci for considering various approaches to the well-being of the embryo/fetus/child in the context of reproductive autonomy. The German law is more protective concerning the extra-corporeal embryo, whereas the intra-corporeal embryo/fetus is much less protected ("Fristenregelung"; see Hepp 2003) and abortion for medical reasons (which include prenatal

\footnotetext{
7 http://www.atid-il.org.il/content. Accessed: 14 July 2021.
} 
genetic diagnosis) is allowed without time limit almost until birth. ${ }^{8}$ The protection of the extra-corporeal embryo is evident in the German unique legal limitation which allows the freezing of fertilized eggs at the pronuclear state, while limiting the cryopreservation of pre-embryos. The German embryo protection law (1991) also stipulates that no more than three embryos can be created per cycle of IVF and all three, regardless of their quality, must be transferred to the patient's womb at one time, and cannot be frozen or discarded (for a more general discussion of IVF regulation in Germany see Jasanoff and Metzler 2020).

The Israeli law is more permissive concerning extra-corporeal embryos, whereas the intra-corporeal embryo/fetus is (formally, at least) more protected by hospital and national abortion termination committees that women have to apply to and come before. This general assertion, however, should be problematized since in practice about $99 \%$ of abortion requests are approved, and the Israeli embryo is generally constructed as gradually accumulating human moral status (Hashiloni-Dolev 2006, 2007).

Our analysis has attempted to make transgressive juxtapositions. When settings for potential intervention that have been looked at and regulated independently by policy-makers are considered (as is often the case from the perspective of users) in the context of other related instances of reproductive regulation, open questions emerge. If prenatal genetic testing, including NIPT, followed by termination of pregnancy is permitted for conditions such as Down syndrome, then should not PGD be arguably allowed to select against similar conditions, if the prospective parents request it as part of IVF? In addition, if sibling donations by already existing siblings are permitted, is it right or wrong to categorically prohibit the use of PGD to select for such donor siblings? These questions become highlighted and in turn highlight their cultural embeddedness when considered against the spectrum of interventions and the gaps between regulatory ideals and actual practices.

Such a comparison of policies enables to substantiate debates on how future children, (pre)embryos and fetuses should be treated from a moral point of view, and how this is part of the moral and cultural meaning of natality, parenthood, the family, and generativity (Wiesemann 2010, 2006; Schües 2008; Heyd 1998, 1995). PGD and NIPT also highlight gradualist and immanent approaches to the acquisition of moral/human status at the beginning of life (Evans 2010). These technological practices also conjure new questions and responsibilities for parents who are facing different options of knowing the genetic condition of their child, options which may lead to selection against or for certain traits ( $\operatorname{Raz} 2009)$.

Second, in modern capitalist societies like Germany and Israel, concerns for the well-being of children in the context of health governance are inevitably embedded in economic considerations of cost-benefit. Scholars have criticized the linkage between financial incentives of providers and the expansion of prenatal genetic

\footnotetext{
8 According to the German law from 1995, abortion is exempt from punishment if the conception is not older than 12 weeks, the abortion must be carried out by a doctor and the women must seek advice beforehand. The former "embryopathic" (sometimes also called "eugenic") indication was dropped by the legislator in 1995 in order to clarify that a life with or without disability deserves the same protection. However, a future child's disability can be interpreted as a threat to the physical or mental health of the mother and thereby serves as an indirect reason for a legal termination.
} 
screening in Israel (Kannai and Chertok 2006). However, while NIPT was widely criticized in Germany but not in Israel, Germany now covers it by public health insurance under certain conditions while Israel decided not to cover NIPT in its public "health basket".

Third, these technological practices have also been studied as highlighting different emphases and transformations in the context of care/prevention/abortion. NIPT is usually about prevention/abortion, although it may also be used to provide parents with early options of care; PGD, enabling both positive and negative selection, embodies a novel combination of care and prevention/selection. One of the most profound changes with NIPT may be the introduction of a pre-emptive objective in prenatal diagnosis. In the future, NIPT could be done to enable an early start with risk-reducing or preventive medical measures either right after birth or even before birth, for example in the case of cystic fibrosis (Hill et al. 2015). This path could rather lead to a concept of care-which is a concern of some German activists who criticize NIPT - for the whole family. Thus, the technology might meet its critics.

\section{Cultural embeddedness of bioethical and regulatory reasoning}

A cultural explanation for the contrasting regulation of HLA-PGD in Germany and Israel was previously provided by Hashiloni-Dolev and Shkedi (2007, 2010) who argue that the key is divergent perceptions of family ethics and the ideal relationships between family members. Opposition to HLA-PGD in Germany, along this argument, stems from a view of family members as first and foremost individuals holding autonomous rights, with a view of different family members as potentially having conflicting interests, rather than idealizing the family as totally harmonious (Hashiloni-Dolev and Shkedi 2007). In contrast, support of HLA-PGD in Israel stems from an ideal view of the family as a unified body of members with similar interests. PGD for sibling donors is hence viewed in Israel as a blessing which serves all family members, rather than as a medical procedure creating family conflicts (Hashiloni-Dolev and Shkedi 2007). The debates over NIPT, too, demonstrate different normative reasonings concerning the individual and the family. In Israel NIPT is promoted as reducing family suffering, thus prioritizing the interests of "the family", while in Germany it is often criticized as compromising disability rights and self-determination in the face of eugenic social pressures.

However, other studies in Germany do not match these generalizations. In a leading compendium about the idea of family we find that "the family provides central social tasks and services in intergenerational relationships within the family: Personal autonomy, identity development, the learning of cultural patterns of action and social reproduction" (Ecarius 2007, p. 9). Recent studies show that children are more and more valued for the creation, value and functioning (or non-functioning) of family (Dorbritz and Diabaté 2015; Dorbritz and Ruckdeschel 2015; Schües 2020). Thus, not the marriage or the idea of living together but the child (particularly the first child) is taken as pivot for "officially" founding the family.

Such a comparison regarding family values highlights cross-cultural moral pluralism, but also the complexity of generalizing overarching societal values and the 
need for empirical studies to highlight the gaps that might exist between declarative values and actual norms. The differences should not be oversimplified by a single overarching general explanation but should be rather discussed as an interaction between different cultural factors and normative arrangements.

Furthermore, there are evidently other cultural themes in addition to family ethics. German opposition to HLA-PGD also includes normative assessments regarding loss of dignity through instrumentalization, the killing of discarded pre-embryos, and the disability critique of prenatal diagnosis/selection. Cultural scripts explaining the permissive approach towards HLA PGD in Israel include trust in medicine, parental responsibility, and pro-eugenic factors. Similarly, one could argue that a difference in the social outlook on disability (as suffering vs. biodiversity) explains the contrasting public reception/debate of NIPT, in Israel and Germany.

Moreover, we can see a similar inconsistency within each country's national regulation, if, rather than looking at the regulation of HLA-PGD as a stand-alone setting, we consider it in the context of other related instances of reproductive regulation. The German law is more protective concerning the extra-corporeal embryo (as in PGD), whereas the intra-corporeal embryo/fetus is relatively much less protected ("Fristenregelung"). This also means that even though NIPT will be covered by German public health insurance when indicated based on the woman's personal situation, it has the potential (due to its early stage) to raise new complexities in decision-making about abortion due to embryopathies (Friese 2017). In contrast, the Israeli law is more permissive concerning extra-corporeal embryos, whereas the intra-corporeal embryo/fetus is relatively more protected. No single theme of normative assessment can explain this. Moreover, the recent change in the German regulation of PGD (allowing it for negative selection under the condition of individual case-by-case consideration by a specialized ethics board), as well as the inclusion of NIPT within the public health insurance under certain conditions, demonstrate that medicolegal regulation can be flexible, rather than being fixated upon some deep-seated cultural mores.

It is possible that a society would want to "protect" those parents who might be morally forced to use HLA-PGD from getting into a moral dilemma which can lead to a very problematic family situation and to the burdensome life of the sibling donor. However, if a society issues such a ban, it should think about how to offer realistic alternatives to save the life of the sick child either from unrelated donors or from public cord blood banks or by putting more effort into research to avoid such difficult moral constellations which are culturally handled in very different ways.

The comparison of NIPT regulations and debates in Germany and Israel highlights their different cultural discourses of disability rights and prenatal diagnosis. The heated debate in Germany regarding routinization, namely the standard offer of NIPT within the public health system, demonstrated the concern regarding eugenic pressures that may hamper the self-determination of (prospective) parents and discriminate against those yet unborn as well as those living with disabilities. Such concerns also go back to the classic Wilson and Jungner (1968) criteria, regarding screening for abnormalities for which no prevention or treatment is possible. This was also the crux of the protest raised by the German disability advocacy groups against NIPT. NIPT does not, indeed, offer any treatment or prevention of 
the abnormalities it screens for (except for "primary prevention" i.e. selective abortion-which is a contested notion of prevention). The pro-NIPT Israeli argument, in contrast, which is supported also by representatives of disability advocacy organizations, stresses it as enhancing parental reproductive autonomy as means to reduce suffering (Nov-Klaiman et al. 2019). Yet such a defense in the form of trusting people to decide for themselves may be unrealistic, given that public health discourse about the cost-benefits alongside the very act of universal coverage and offer often normalize the act of testing/screening. A fresh examination of these routines, and the way they are linked to decision-making practices will become increasingly relevant and important.

Funding Part of this work was supported by Deutsche Forschungsgemeinschaft (grant number 314959264 , funding reference: SCHU 2846/2-1; RE 2951/3-1).

Funding Open Access funding enabled and organized by Projekt DEAL.

Open Access This article is licensed under a Creative Commons Attribution 4.0 International License, which permits use, sharing, adaptation, distribution and reproduction in any medium or format, as long as you give appropriate credit to the original author(s) and the source, provide a link to the Creative Commons licence, and indicate if changes were made. The images or other third party material in this article are included in the article's Creative Commons licence, unless indicated otherwise in a credit line to the material. If material is not included in the article's Creative Commons licence and your intended use is not permitted by statutory regulation or exceeds the permitted use, you will need to obtain permission directly from the copyright holder. To view a copy of this licence, visit http://creativecommons.org/licenses/by/4. $0 /$.

\section{Declarations}

Conflict of interest A.E. Raz, T. Nov-Klaiman, Y. Hashiloni-Dolev, H. Foth, C. Schües and C. RehmannSutter declare that they have no competing interests.

Ethical standards For this article no studies with human participants or animals were performed by any of the authors. All studies performed were in accordance with the ethical standards indicated in each case.

\section{References}

Akrich M (1992) The de-scription of technical objects. In: Bijker W, Law J (eds) Shaping technology/ building society: studies in sociotechnical change. MIT Press, Cambridge, pp 205-224

Al Mahri GA, Nicolaides KH (2019) Evolution in screening for Down syndrome. Obstet Gynaecol 21(1):51-57

Asch A, Barlevy D (2012) Disability and genetics: a disability critique of pre-natal testing and pre-implantation genetic diagnosis (PGD). eLS. https://doi.org/10.1002/9780470015902.a0005212.pub2

Benedict XVI, Sovereign Pontiff (2008) Congregation for the doctrine of the faith instruction dignitas personae on certain bioethical questions. http://www.vatican.va/roman_curia/congregations/cfaith/ documents/rc_con_cfaith_doc_20081208_dignitas-personae_en.html. Accessed 14 July 2021

BGH (2010) Urteil 6 July 2010 — 5 StR 386/09. http://juris.bundesgerichtshof.de/cgi-bin/rechtsprechung/ document.py?Gericht=bgh\&Art=en\&nr=52897\&pos=0\&anz=1. Accessed 14 July 2021

Bowker G, Star SL (1999) Sorting things out. MIT Press, Cambridge

Braun K, Könninger S (2018) Realizing responsibility: Institutional routines, critical intervention, and the "big" questions in the controversy over non-invasive prenatal testing in Germany. New Genet Soc 37(1):1-20

DeGrazia D (2012) Creation ethics: reproduction, genetics, and quality of life. Oxford University Press, Oxford

Deutscher Ethikrat (ed) (2011) Präimplantationsdiagnostik. Stellungnahme. http://www.ethikrat.org/ dateien/pdf/stellungnahme-praeimplantationsdiagnostik.pdf. Accessed 14 July 2021 
Dorbritz J, Diabaté S (2015) Kulturelle Vorstellungen zum Leben ohne Kinder. In: Schneider NF, Diabaté S, Ruckdeschel K (eds) Familienleitbilder in Deutschland. Kulturelle Vorstellungen zu Partnerschaft, Elternschaft und Familienleben. Barbara Buderich, Berlin, Toronto, pp 113-132

Dorbritz J, Ruckdeschel K (2015) Leitbilder der Familiengründung und der Familienerweiterung. In: Schneider NF, Diabaté S, Ruckdeschel K (eds) Familienleitbilder in Deutschland. Kulturelle Vorstellungen zu Partnerschaft, Elternschaft und Familienleben. Barbara Buderich, Berlin, Toronto, pp 133-154

Düwell M, Mieth D, Knoerzer U (1998) Ethik in der Humangenetik. Die neueren Entwicklungen in der genetischen Frühdiagnostik aus ethischer Perspektive. Francke, Tübingen

Ecarius J (2007) Handbuch Familie. Springer VS, Wiesbaden

Evans J (2010) Contested reproduction: genetic technologies, religion, and public debate. University of Chicago Press, Chicago

Even D (2013) Children of the moon: new ways to prevent autism. Haaretz 13.01. https://www.haaretz.co. il/news/health/1.1905406. Accessed 21 July 2021 (in Hebrew)

Friese S (2017) Die Nicht-invasiven Pränataltests unterwegs in der globalisierten Pränataldiagnostik: ein herausforderndes Beispiel aus der Praxis. In: Friese S et al (ed) Pränatale Diagnostik: Beratungspraxis aus medizinischer, psychosozialer und ethischer Sicht, vol 41. Campus, Frankfurt, pp 69-79

Gemeinsamer Bundesausschuss (G-BA) (2016) Pressmitteilung Nr. 32/2016: Methodenbewertung Nichtinvasive Pränataldiagnostik bei Risikoschwangerschaften - G-BA beginnt Verfahren zur Methodenbewertung - Beratungen zur Erprobung ruhend gestellt, Berlin, 18.08.2016. https://www.g-ba.de/ downloads/34-215-635/32_2016-08-18_Methodenbewertung\%20NIPD.pdf. Accessed 21 Aug 2017

Gen-ethisches Netzwerk e.V., Netzwerk gegen Selektion durch Pränataldiagnostik, Diakonisches Werk der evangelischen Kirche in Württemberg e.V. (2017) Stellungnahme: Keine Aufnahme weiterer selektiver Untersuchungen in die Regelversorgung! https:/www.gen-ethisches-netzwerk.de/ praenataldiagnostik/keine-aufnahme-weiterer-selektiver-untersuchungen-die-regelversorgung. Accessed 14 Feb 2017

Gregg A, Skotko B, Benkendorf J et al (2016) Noninvasive prenatal screening for fetal aneuploidy, 2016 update: a position statement of the American College of Medical Genetics and Genomics. Genet Med 18:1056-1065

Griffin B, Edwards S, Chitty LS, Lewis C (2018) Clinical, social and ethical issues associated with noninvasive prenatal testing for aneuploidy. J Psychosom Obstet Gynecol 39(1):11-18

Habermas J (2003) The future of human nature. Polity Press, Cambridge

Haidar H, Vanstone M, Laberge AM, Bibeau G, Ghulmiyyah L, Ravitsky V (2020) Implementation challenges for an ethical introduction of noninvasive prenatal testing: a qualitative study of healthcare professionals' views from Lebanon and Quebec. BMC Med Ethics 21(1):15. https://doi.org/10.1186/ s12910-020-0455-X

Harari S (2005) A present for the future. Kinneret Zmora-Bitan Dvir Publishing House, (Hebrew)

Harris J (1998) Genes clones and immortality. Routledge, London

Hashiloni-Dolev Y (2006) Between mothers, fetuses and society: reproductive genetics in the Israeli-Jewish context. Nashim J Jew Womens Stud Gend Issues 12:129-150

Hashiloni-Dolev Y (2007) A life (un)worthy of living: reproductive genetics in Israel and Germany. Springer-Kluwer, Berlin

Hashiloni-Dolev Y, Shkedi S (2007) On new reproductive technologies and family ethics: Pre-implantation genetic diagnosis for sibling donor in Israel and Germany. Soc Sci Med 65(10):2081-2092

Hashiloni-Dolev Y, Shkedi S (2010) The regulation of preimplantation genetic diagnosis for sibling donors in Israel, Germany and England: a comparative look at balancing risks and benefits. In: BirenbaumCarmeli D, Carmeli Y (eds) Kin, gene, community: reproductive technologies among Jewish Israelis. Berghahn, Oxford, pp 61-83

Henning T (2014) Instrumentalisierung und Kants Zweckformel. Ethik Med 26:195-209

Hens K et al (2013) Dynamics and ethics of comprehensive preimplantation genetic testing: a review of the challenges. Hum Reprod Update. https://doi.org/10.1093/humupd/dmt009

Hepp H (2003) Pränatalmedizin und Embryonenschutz - ein Widerspruch der Werte. Gynäkologe 36(7):572-581

Herzog M et al (2021) Stem cell transplantations between siblings as social phenomena. The child's body and family decision-making. Springer, Berlin (in press)

Heyd D (1995) Prenatal diagnosis: whose right? J Med Ethics 21:292-297

Heyd D (1998) Are we our descendants' keepers? In: Agius E, Busuttil S (eds) Germ-line intervention and our responsibilities to future generations. Kluwer, Dordrecht, pp 131-145 
Hill M, Twiss P, Verhoef TI et al (2015) Non-invasive prenatal diagnosis for cystic fibrosis: detection of paternal mutations, exploration of patient preferences and cost analysis. Prenat Diagn 35(10):950-958. https://doi.org/10.1002/pd.4585

Israeli Parliament (Knesset) (2005) PGD for sex selection and other medical purposes. The Science and Technology Committee, protocol number 124. http://www.knesset.gov.il/protocols/data/rtf/mada/ 2005-03-16.rtf. Accessed 14 July 2021

Jasanoff S, Metzler I (2020) Borderlands of life: IVF embryos and the law in the United States, United Kingdom, and Germany. Sci Technol Hum Values 45(6):1001-1037. https://doi.org/10. $1177 / 0162243917753990$

Kannai R, Chertok IR (2006) Prenatal panel screening considerations for non-neuronopathic Gaucher disease in the Ashkenazi-Jewish population. Isr Med Assoc J 8(5):347-350

Kollek R (2002) Preimplantationsdiagnostik. Embryonenselektion, weibliche Autonomie und Recht. Francke, Tubingen

Labonté V, Alsaid D, Lang B et al (2019) Psychological and social consequences of non-invasive prenatal testing (NIPT): a scoping review. BMC Pregnancy Childbirth 19:385. https://doi.org/10.1186/ s12884-019-2518-X

Landau R (2008) Sex selection for social purposes in Israel: quest for the "perfect child" of a particular gender or centuries old prejudice against women? J Med Ethics 34:e10

Löwy I (2020) ART with PGD: Risky heredity and stratified reproduction. Reprod Biomed Soc Online 11:48-55

Maio G (2007) Der Status des extrakorporalen Embryos. Perspektiven eines interdisziplinären Zugangs. Frommann-Holzboog, Bad Cannstatt

McGee G (2000) The perfect baby. Parenthood in the new world of cloning and genetics, 2nd edn. Rowman \& Littlefield, NY

Merkel R (2002) Forschungsobjekt Embryo. Verfassungsrechtliche und ethische Grundlagen der Forschung an menschlichen embryonalen Stammzellen. dtv, München

Ministry of Health, State of Israel (2006) Guidelines for preimplantation genetic diagnosis. Circular 50/2006. http://www.health.gov.il/download/forms/a2930_mr50_06.pdf. Accessed 14 July 2021 (Hebrew)

Ministry of Health, State of Israel (2013) Guidelines for implementing preimplantation genetic diagnosis. Circular 29/2013. https://www.health.gov.il/hozer/mr29_2013.pdf. Accessed 14 July 2021 (Hebrew)

Nov-Klaiman T, Raz A, Hashiloni-Dolev Y (2019) Attitudes of Israeli parents of children with Down syndrome toward non-invasive prenatal screening and the scope of prenatal testing. J Genet Couns 28(6):1119-1129. https://doi.org/10.1002/jgc4.1162

Parens E, Asch A (eds) (2000) Prenatal testing and disability rights. Georgetown University Press, Washington, D.C.

Pro familia Bundesverband (2019) NIPT - Nicht-invasiver Pränataltest als Leistung der GKV? Stellungnahme des pro familia Bundesverbands im Rahmen des Stellungnahme-Verfahrens des G-BA, 11.04.2019. https://www.profamilia.de/ueber-pro-familia/stellungnahmen. Accessed 14 July 2021

Ravitsky V et al (2021) The emergence and global spread of noninvasive prenatal testing. Annu Rev Genom Hum Genet 22:1. https://doi.org/10.1146/annurev-genom-083118-015053

Raz A (2009) Community genetics and genetic alliances: eugenics, carrier testing, and networks of risk. Routledge, NY, London

Raz A, Schicktanz S (2010) Through the looking glass: engaging in a socio-ethical, cross-cultural dialogue. New Genet Soc 29(1):55-59

Raz A et al (2017) Saving or subordinating life? Popular views in Israel and Germany of donor siblings created through PGD. J Med Humanit 38:191-207

Rehmann-Sutter C (2007) Embryoselektion zur Gewebespende? Fälle von PID-HLA und ihre Analyse in individual- und sozialethischer Perspektive. Ethica 15:115-143

Rehmann-Sutter C (2017) PID auf Aneuploidie des Embryos? Ethische Überlegungen zur Auslegung von $\S 3 \mathrm{a}$ des Embryonenschutzgesetzes in Deutschland. Ethik Med 29:201-216

Rehmann-Sutter C, Schües C (2020) Die NIPT-Entscheidung des G-BA. Eine ethische Analyse. Ethik Med 32:385-403. https://doi.org/10.1007/s00481-020-00592-0

Revel M (ed) (2008) Ethical issues in PGD. Israel National Bioethics Committee and the Israel National Academy of Sciences, Jerusalem (Hebrew)

Reynolds TM (2003) Down's syndrome screening is unethical: views of today's research ethics committees. J Clin Pathol 56(4):268-270

Richter-Kuhlmann E (2011) Präimplantationsdiagnostik: Der Bundestag hat entschieden, dass Gentests an Embryonen künftig erlaubt sein sollen. Dtsch Arztebl 108:1322-1323 
Sandel MJ (2007) The case against perfection: ethics in the age of genetic engineering. Harvard University Press, Cambridge

Schmergal C (2019) Will there still be children with Down syndrome? 13.09.2019, DER SPIEGEL 38/2019. https://www.spiegel.de/politik/trisomie-21-wird-es-kuenftig-noch-kinder-mitdownsyndrom-geben-a-00000000-0002-0001-0000-000165926170. Accessed 14 July 2021

Savulescu J (2001) Procreative beneficience: why we should select the best children. Bioethics 15(5): $413-426$

Schües C (2008) Philosophie des Geborenseins. Karl Alber, Freiburg

Schües C (2017) The trans-human paradigm and the meaning of life. In: Fielding H, Olkowski D (eds) Future directions in feminist phenomenology. Indiana University Press, Bloomington, pp 218-241

Schües C (2020) Familie: Geburt und Verantwortung. In: Ecarius J, Schierbaum A (eds) Handbuch Familie. Springer VS, Wiesbaden, pp 1-19 https://doi.org/10.1007/978-3-658-19861-9_13-1

Schües C, Rehmann-Sutter C (2013) The well- and unwell-being of a child. Topoi 32:197-205. https://doi. org/10.1007/s11245-013-9157-z

Schües C, Rehmann-Sutter C (2015) Rettende Geschwister. Ethische Aspekte der Knochenmarkspende mit Kindern. Mentis, Münster

Schwinger E (2003) Präimplantationsdiagnostik. Medizinische Indikation oder unzulässige Selektion? Friedrich Ebert Stiftung, Bonn

Smith M, Visootsak J (2013) Noninvasive screening tools for Down syndrome: a review. Int J Womens Health 5:125-131

Valkenburg G, Aarden E (2011) Constructing embryos, constructing politics: connecting politics and technology in the Netherlands and Germany. BioSocieties 6:447-465. https://doi.org/10.1057/biosoc. 2011.19

Wiesemann C (2006) Von der Verantwortung, ein Kind zu bekommen. Eine Ethik der Elternschaft. C. H. Beck, München

Wiesemann C (2010) The moral challenge of natality: towards a post-traditional concept of family and privacy in reprogenetics. New Genet Soc 29:61-71

Wilson J, Jungner G (1968) Principles and practice of screening for disease. WHO, Geneva

Woopen C (1999) Präimplantationsdiagnostik und selektiver Schwangerschaftsabbruch. Zur Analogie von Embryonenselektion in vitro und Schwangerschaftsabbruch nach Präimplantationsdiagnostik im Rahmen der medizinischen Indikation des §218a Abs.2 StGB aus ethischer Perspektive. Z Med Ethik 45:233-244

Zuckerman S, Zeevi D, Gooldin S, Altarescu G (2018) Acceptable applications of preimplantation genetic diagnosis (PGD) among Israeli PGD users. Eur J Hum Genet 25:1113-1117 